\title{
Cancer Cell Dormancy in Metastasis
}

\author{
Matthew A. Summers, ${ }^{1,2}$ Michelle M. McDonald, ${ }^{1,2}$ and Peter I. Croucher ${ }^{1,2}$ \\ ${ }^{1}$ Bone Biology, The Garvan Institute of Medical Research, Sydney 2010 NSW, Australia \\ ${ }^{2}$ St Vincent's Clinical School, University of New South Wales, Faculty of Medicine, Sydney 2052 NSW, Australia \\ Correspondence: p.croucher@garvan.org.au
}

Recurrent metastasis following extended periods of disease-free survival remains a common cause of morbidity and mortality for many cancer patients. Recurrence is thought to be mediated by tumor cells that escaped the primary site early in the disease course and colonize distant organs. In these locations, cells adapt to the local environment, entering a state of longterm dormancy in which they can resist therapy. Then, through mechanisms that are poorly understood, a proportion of these cells are reactivated and become proliferative, forming lethal metastases. Here, we discuss disseminated tumor cell dormancy in recurrent metastasis. We discuss mechanisms known to control entrance of cells into dormancy, highlighting the relevant microenvironments or "niches" in which these cells reside and mechanisms known to be involved in dormant cell reactivation. Finally, we consider emerging therapeutic approaches aimed at eradicating residual disease and preventing metastatic relapse.

\begin{abstract}
$A$ dvances in our understanding of cancer biology, alongside improved clinical management strategies, has seen survival rates following a cancer diagnosis increase dramatically since the 1970s, for both childhood and adult cancers (Quaresma et al. 2015). However, despite this achievement, many challenges remain. A critical problem is disease recurrent metastasis: a difficult to treat and often deadly consequence of the early systemic dissemination and long-term survival of cancer cells, through mechanisms that remain incompletely understood.

In this article, we will review the phenomenon of disseminated cancer cell dormancy. We will focus on cancer cells that escape the primary tumor early in the disease course and colonize distant sites, surviving for long periods of time in a reversibly inactive or "dormant" state, be-
\end{abstract}

fore their subsequent reactivation and metastatic outgrowth, sometimes years after the patient is believed to be cancer-free.

\section{CANCER CELL DORMANCY IN DISEASE PROGRESSION}

It is important to first clarify how we define the term dormancy, as it is applied broadly in the cancer literature and often refers to different phenomena. One form of dormancy refers to dormancy of a tumor mass: the cessation of growth (or the constant size) of a whole tumor, either at a primary or metastatic site. Although cells within the tumor may be replicating, the overall mass is constrained and does not expand because of the equivalent rates of cell death (Yeh and Ramaswamy 2015). Cell death in this

Editors: Jeffrey W. Pollard and Yibin Kang

Additional Perspectives on Metastasis: Mechanism to Therapy available at www.perspectivesinmedicine.org

Copyright (C) 2020 Cold Spring Harbor Laboratory Press; all rights reserved; doi: 10.1101/cshperspect.a037556

Cite this article as Cold Spring Harb Perspect Med 2020;10:a037556 
M.A. Summers et al.

context is typically caused by either physical limitations such as hypoxia and limited vascularization, and is often called "angiogenic dormancy" (Yeh and Ramaswamy 2015), and/or a continued clearance of proliferating cells by the immune system maintaining the tumor mass, termed "immunologic dormancy" (Yeh and Ramaswamy 2015). An alternative to this concept is the concept of "cellular dormancy," a reversible nondividing state attained by single tumor cells attempting to adapt and survive in changing environments (Hadfield 1954; Sosa et al. 2014; Yeh and Ramaswamy 2015). This review is principally concerned with the biology and mechanisms of cellular dormancy as they relate to relapsing metastasis.

\section{Historical and Modern Perspectives}

The concept of disseminated tumor cell dormancy developed principally from clinical observations. One of the earliest cases was documented in 1934 by Australian pathologist Rupert Willis, in which he described the notion of cancer cell dormancy as an explanation for recurrent metastases observed long after a patient's primary disease treatment:

"When long delayed metastatic tumors appear in patients in whom there is no local recurrence of the extirpated primary growth, it is clear that the secondary growths must have arisen from tumoremboli disseminated from the primary growth before its removal. The neoplastic cells must have lain dormant in the tissues in which they were arrested, and their resumption of growth must be attributed to some alteration in the qualities of these tissues or to some release of growth restraints exercised by them on tumor cells" (Willis 1934).

Since this early concept that recurrent metastases are growths derived from previously disseminated and dormant tumor cells, decades of clinical observations have corroborated this original assumption (Sosa et al. 2014; Friberg and Nyström 2015; Kim et al. 2015; Yeh and Ramaswamy 2015; Liu et al. 2017). For example, in patients with recurrent breast and prostate cancer metastases, relapse can be seen years or even decades following successful primary treatment (Zhang et al. 2013; van der Toom et al. 2016). Recurrent metastases are similarly observed in renal cell (McNichols et al. 1981; Kucharczyk and Matrana 2016) and soft tissue carcinomas (Toulmonde et al. 2014), and in malignant melanomas, in which relapse can occur up to $15 \mathrm{yr}$ later (Faries et al. 2013), and in rare cases after more than $40 \mathrm{yr}$ of disease-free survival (Terhorst et al. 2010; Saleh and Peach 2011). Furthermore, examples of tumor cell dormancy come from modern organ transplantation studies, in which inadvertent transfer of malignant cells has occurred between organ donor and organ recipient, even though donors were believed to be cured of their cancer up to a decade prior to transplantation (Friberg and Nyström 2015).

\section{DORMANT CANCER CELLS EXIST IN NICHES}

One of the challenges in understanding tumor cell dormancy is the variety of tissues in which these cells are found. Common sites harboring disseminated cells include soft tissues such as the lung, brain, lymph nodes, and liver (Cowie et al. 1997; Edry Botzer et al. 2011; Singh et al. 2014), as well as calcified skeletal tissues (Croucher et al. 2016). The cell type heterogeneity within these microenvironments makes understanding common and distinct dormancy mechanisms challenging, however, progress is being made in this area.

Accumulating evidence suggests that cellextrinsic microenvironmental mechanisms regulating endogenous cell dormancy are hijacked by disseminated tumor cells for their own survival advantage. For example, hematopoietic stem cells (HSCs) are capable of long-term survival in reversible states of dormancy (Wilson et al. 2008) and these are regulated through interactions with their unique tissue microenvironments or "niches" in bone (Wilson et al. 2007). Disseminated tumor cells of several cancer types have been reported to hijack these endogenous HSC regulatory mechanisms. For example, the CXCL12 chemokine signaling axis (Liekens et al. 2010) is a critical regulator of HSC homing and quiescence (Sugiyama et al. 2006), and is used by both prostate cancer and breast cancer cells during colonisation of bone and entrance into dormancy (Shiozawa et al. 2011; Conley-LaComb et al. 2016; Price et al. 
2016). Additionally, diverse cell types within the HSC niche, including the perivascular endothelial cells of the blood vessels (Ding et al. 2012) and neighboring mesenchymal populations, including osteoblastic cells and adipocytes (Askmyr et al. 2009; Naveiras et al. 2009), all play critical endocrine and paracrine roles in niche homeostasis and dormancy.

Although the niches in bone remains some of the most well studied microenvironments related to cancer cell dormancy, it is plausible that comparable vascular-related mechanisms also control dormancy outside bone. Indeed, perivascular cell interactions are known to be involved in dormancy of brain metastases (Kienast et al. 2010), and hepatic stellate cells of the sinusoidal capillaries may be involved in pancreatic ductal adenocarcinoma dormancy in the liver (Lenk et al. 2018; Fabian et al. 2019). Nevertheless, some aspects of the cell-extrinsic and molecular control of tumor cell dormancy are likely to be organ specific, particularly those involving tissue-restricted cell types such as osteoblasts in bone (Croucher et al. 2016). Indeed, tumor cell dormancy in models of multiple myeloma has been shown to be osteoblastic niche specific (Chen et al. 2014; Lawson et al. 2015), with pathway targeted interventions affecting skeletal but not spleen resident dormant cell numbers (Khoo et al. 2019). Understanding and distinguishing organ-specific from organ-independent mechanisms of dormancy is an important and ongoing research goal.

\section{MOLECULAR MECHANISMS GOVERNING ENTRANCE INTO DORMANCY}

A number of cell-signaling pathways have been implicated in the induction of tumor cell dormancy. Canonical ERK/p38 mitogen-activated protein kinase (MAPK) activation regulated via transforming growth factor (TGF)- $\beta$ signaling has been shown to induce dormancy of head and neck squamous cell carcinoma cells in bone (Bragado et al. 2013). Additionally, osteoblasts expressing high levels of secreted TGF $\beta 2$ activate p38 MAPK in human prostate cancer cell lines, inducing dormancy (Yu-Lee et al. 2018). Indeed, this pathway appears to be a canonical dor- mancy regulator. In several cancer lines including breast, prostate, melanoma, and fibrosarcoma cell lines, the phosphorylated ERK/p38 ratio can predict tumor growth and cellular dormancy status in vivo (Aguirre-Ghiso et al. 2003). Stress signaling through these pathways regulates mitogenic signaling and can induce cell cycle arrest via expression of a network of transcription factors (Bulavin and Fornace 2004; Adam et al. 2009). Furthermore, expression of p38 target genes in the uncoupling protein response pathway can predict patient relapse (Lin et al. 2007; Schewe and Aguirre-Ghiso 2008); whereas p38 isoform expression up-regulates endoplasmic reticulum chaperone proteins, conferring chemotherapeutic resistance to dormant cells (Ranganathan et al. 2006).

Cellular dormancy can also be induced by signaling through TAM receptor tyrosine kinases; in both solid tumors and haematological cancers. For example, the tyrosine kinase receptors TYRO3, MER, and AXL, are critical for native HSC dormancy control, and this pathway controls prostate cancer cell dormancy in bone through binding of the osteoblast factor GAS6 (Shiozawa et al. 2010a; Taichman et al. 2013; Yumoto et al. 2016). Similarly, lymphoblastic leukaemia cells are induced into a state of dormancy by binding of GAS6 to MER, conferring extended survival and chemotherapeutic resistance via a MAPK-dependant mechanism (Shiozawa et al. 2010b). When multiple myeloma cells interact with osteoblastic cells in vivo, they enter a state of dormancy, mediated by the induction of a suite of myeloid lineage related genes in the tumor cells (Khoo et al. 2019). AXL is a key induced gene in this context and blocking AXL was associated with release of cells from dormancy (Khoo et al. 2019). Notably, AXL and nearest-neighbor genes were able to distinguish patients with myeloma from normal subjects, and those with the premalignant monoclonal gammopathy of undetermined significance. This dormant cell myeloid signature was also able to predict survival, pointing to an important functional role (Khoo et al. 2019).

In addition to these pathways, dormancy can be induced by several other likely interrelated systems, including stromal cell bone 
M.A. Summers et al.

morphogenetic protein signaling (Buijs et al. 2007; Kobayashi et al. 2011), TGF- $\beta$ related pathways (Prunier et al. 2019), nutrient deprivation (Jo et al. 2008), hypoxia (Fluegen et al. 2017), and autophagy response pathways (Mowers et al. 2017). Ultimately, tumor cell dormancy involves attaining a state of reversible cell-cycle arrest via a complex interaction between the tumor cell and the heterogeneous surrounding environment that they reside within. Improving our understanding of how these and other pathways regulate tumor cell dormancy will advance our understanding of the mechanisms driving the escape from dormancy and the development of disease.

\section{DORMANT TUMOR CELL REACTIVATION}

Tumor cells arriving in a niche will engage with the surrounding microenvironment, and mount a series of adaptive responses involving cellintrinsic signaling programs. These adaptations in concert with niche-specific extrinsic paracrine signaling, ultimately results in the induction of cellular dormancy and long-term tumor cell survival. What is much less well understood is the subsequent process of dormant cell reactivation, a seemingly stochastic event involving a proportion of cells escaping from dormancy and initiating metastatic outgrowth via mechanisms that remain poorly characterized.

Recent work has highlighted novel immune cell inflammatory mechanisms by which dormant cancer cells in the lung can be reactivated to form aggressive metastases. During sustained inflammation, lung resident neutrophils were shown to produce a secreted extracellular trap, a mixture of excreted DNA and cytotoxic proteins and proteases targeting foreign immunogenic material. This neutrophil extracellular trap initiated the reactivation of dormant breast and prostate cancer cells in the lung through remodeling of the surrounding extracellular matrix, resulting in aggressive lung metastases (Albrengues et al. 2018). Indeed, integrin and extracellular matrix remodeling events have previously been described as central dormant cell reactivation mechanisms (Aguirre Ghiso et al. 1999; Hamidi et al. 2016). These immune relat- ed inflammatory pathways present encouraging therapeutic opportunities.

A similar mechanism involving extracellular matrix remodelling is that of tissue angiogenesis, the sprouting of new blood vessels from existing vascular structures. This process involves vascular endothelial cells remodelling the extracellular environment through integrin receptor binding to allow new vessels to form (Stupack and Cheresh 2004; Avraamides et al. 2008). Dormant tumor cells residing in perivascular niches associated with vessels are retained in a dormant state through endothelial thrombospondin-1, and can be released from dormancy during neovascular formation (Ghajar et al. 2013). Notably, a stable endothelium constituted a dormancy niche, whereas neovascular tip cells promoted reactivation through the expression of tumorpromoting factors periostin and TGF- $\beta 1$ (Ghajar et al. 2013).

Vascular and extracellular matrix related mechanisms are of particular interest when studying dormant cell reactivation, as they may represent system wide and organ-independent pathways. Equally important, although unlikely mutually exclusive, are organ-specific mechanisms involving tissue-restricted cell types; such as the involvement of skeletal resident osteoclastic cells in bone. In preclinical models of bone metastasis, interventions stimulating osteoclast remodeling of the bone compartment, including castration (Ottewell et al. 2014), ovariectomy (Ottewell et al. 2015), and vitamin D deficiency (Ooi et al. 2010), are all capable of driving reactivation of a proportion of dormant cells present in bone; suggesting a central role for osteoclast remodeling in the reactivation of dormant cells. In preclinical models of multiple myeloma, dormant tumor cells were visualized residing on the endosteal bone surface and RANK-ligand stimulated osteoclast remodeling of the niche reactivated a subset of dormant cells and initiated tumor proliferation (Lawson et al. 2015). This points to an organ restricted cell type, in this case the osteoclast, remodeling the environment to release cells from nichedependent control. In support of this, tumor cells themselves may be capable of recruiting osteoclasts to facilitate dormant cell reactivation. 
It has been shown that vascular cell adhesion molecule-1 (VCAM-1) expression on dormant breast cancer cells recruits osteoclast progenitors through their expression of the integrin $\alpha 4 \beta 1$, ultimately driving tumor cell reactivation and the vicious cycle of bone destruction and tumor expansion (Lu et al. 2011). VCAM1 and $\alpha 4$ integrin inhibition in this context blunted the progression of metastasis and preserved bone structure (Lu et al. 2011).

Whether osteoclast-mediated reactivation is related to the physical dislodging of cells from the dormant cell niche in which they reside, the associated remodeling of vascular structures in the bone compartment, or the result of the release of growth factors either previously sequestered or newly acquired in the environment, or a combination of all of these, remains to be defined. In any case, these data raise important questions regarding the stochastic nature of reactivation events in bone, particularly in light of evidence suggesting only a limited number of dormant cells are reactivated by osteoclasts at any one time (Lawson et al. 2015). Further work is needed to clarify whether heterogeneity in dormant cell populations exists, and how this relates to their selective reactivation.

\section{CLINICAL PERSPECTIVES IN CANCER MANAGEMENT}

Managing the burden of recurrent metastasis remains a significant clinical challenge. Current approaches to treating relapse and metastatic outgrowth from dormancy are largely reactive in nature, although measures designed to prevent relapse are limited. Nonetheless, progress in our understanding of disseminated tumor cell dormancy mechanisms, as well as processes involved in reactivation, are beginning to highlight therapeutic opportunities. For example, one approach is to target tumor cell-extrinsic mechanisms of dormancy reactivation, in an effort to hold disseminated cells in a dormant state indefinitely. This approach may have several advantages. By maintaining the environments that retain cells in a dormant state, patients could be spared more aggressive therapies targeting residual disease and reducing the risk of relapse and increasing survival. Indeed, in the context of bone metastases, bisphosphonate treatment inhibiting osteoclasts to reduce tumor associated skeletal disease, has seen the parallel benefit of reducing metastatic recurrence and improving patient survival in some studies (Morgan et al. 2010; Chlebowski and Col 2011; Coleman et al. 2014; Macherey et al. 2017). Although the mechanism that accounts for this is poorly defined, it is likely that one mechanism is the maintenance of the dormancy niche in bone and reduced osteoclast-mediated reactivation. Nevertheless, the data offer proof of principle that strategies aimed at maintaining the stability of microenvironments in which dormant cells are known to reside, may alter the clinical course of disseminated disease.

An alternative approach to maintaining cells in a dormant state is to liberate dormant cells from niche-dependent control, thereby making cells more susceptible to conventional chemotherapeutic approaches. Reactivation could be achieved by targeting dormancy pathwayspecific mechanisms, including AXL, p38, or TGF- $\beta 2$ inhibition (Bragado et al. 2013; Khoo et al. 2019), or niche-dependent mechanisms of control. In the case of bone, this could include osteoclast activators such as RANK-ligand (Lawson et al. 2015). This would stimulate tumor cell exit from dormancy and could be followed by treatment with antiproliferative therapies. Although this approach offers potential to eradicate residual disease, it comes with the risk of failing to eradicate all cells and stimulating metastatic tumor growth.

The optimum strategy would be to target dormant cells directly and eradicate them in situ in the dormant cell niche. Targeted inhibition of IGF-1R signaling, as well as chromatin structure remodeling with an histone deacetylase (HDAC) inhibiter is effective at eliminating drug tolerant dormant subpopulations of melanoma, colon, and lung cancer cells (Sharma et al. 2010). This chromatin-modifying approach has also been used as a sensitizing agent in combination therapy approaches with other tumor growth inhibitors (Greve et al. 2015). Besides epigenetic approaches to target dormant cells, metabolic targets may also be promising. It has 
M.A. Summers et al.

been shown that dormant slow-cycling tumor cell populations are highly dependent on mitochondrial respiration, and can be eradicated using oxidative phosphorylation and mitochondrial electron transport chain inhibitors (Roesch et al. 2013; Viale et al. 2014). These findings suggest that combination treatments may be an optimal approach; with chemotherapeutic drugs targeting proliferating cells and metabolic inhibitors targeting dormant slow cycling cells to eliminate residual disease. An alternative dormancy target in this approach could be to use molecules and pathways known to be enriched in dormant cells (Khoo et al. 2019) to develop targeted delivery of cytotoxic killing agents. Finally, immune targeted approaches also hold potential for dormant cell eradication (Goddard et al. 2018). It is known that down-regulation of major histocompatibility (MHC) class 1 is a mechanism by which dormant tumor cells might evade $\mathrm{CD}^{+} \mathrm{T}$ cell recognition (Pantel et al. 1991; Agudo et al. 2018). Data also suggests adaptive immune cells themselves (Koebel et al. 2007) as well as cytokines (Teng et al. 2012) can act to maintain dormancy independent of tumor MHC expression; although this mechanism could be related to the equilibrium phase of immunologic dormancy rather than a specific growth-arrested cellular dormancy mechanism. Nevertheless, continued development of our understanding of the relationship between the immune system and cellular dormancy will aid in the development of treatments to increase dormant cell immunogenicity, revealing dormant cells to the immune system to stimulate endogenous immune-mediated killing as an eradication strategy for residual disease.

\section{SUMMARY AND CONCLUDING REMARKS}

Our understanding of cancer cell dormancy has improved in recent years. This has largely been driven by research in animal models of dormancy. Although the clinical translation of this work has yet to be realized, this remains a priority. The development of new single-cell sequencing technologies and high-resolution imaging now affords opportunities to better understand dormant cancer cells and to the fol- low the evolution of disease from the initiating dormant cell to overt metastasis. This will continue to identify new ways to target and ultimately eradicate these cells. Furthermore, this knowledge may prove important in predicting who will develop metastatic disease in the future and who requires treatment now to stop this happening in the future. Continued work on understanding the genetic heterogeneity in dormant cell populations, as well as mechanisms of dormant cell drug resistance and reactivation, holds the key to developing single targeted or combination treatment approaches to eradicate residual disease affecting a true cure for metastatic cancers.

\section{ACKNOWLEDGMENTS}

M.A.S. and P.I.C. acknowledge the support of the Prostate Cancer Foundation of Australia and The Movember Foundation, M.M.M. and P.I.C. acknowledge the support of Mrs. Janice Gibson and the Ernest Heine Family Foundation, and M.M.M. acknowledges the support of the Cancer Council New South Wales, and the Cancer Institute NSW for Career Development Fellowship funding.

\section{REFERENCES}

Adam AP, George A, Schewe D, Bragado P, Iglesias BV, Ranganathan AC, Kourtidis A, Conklin DS, AguirreGhiso JA. 2009. Computational identification of a $\mathrm{p}^{38 \mathrm{SAPK}}$-regulated transcription factor network required for tumor cell quiescence. Cancer Res 69: 5664-5672. doi:10.1158/0008-5472.CAN-08-3820

Agudo J, Park ES, Rose SA, Alibo E, Sweeney R, Dhainaut M, Kobayashi KS, Sachidanandam R, Baccarini A, Merad M, et al. 2018. Quiescent tissue stem cells evade immune surveillance. Immunity 48: 271-285.e5. doi:10.1016/j .immuni.2018.02.001

Aguirre Ghiso JA, Kovalski K, Ossowski L. 1999. Tumor dormancy induced by downregulation of urokinase receptor in human carcinoma involves integrin and MAPK signaling. J Cell Biol 147: 89-104. doi:10.1083/ jcb.147.1.89

Aguirre-Ghiso JA, Estrada Y, Liu D, Ossowski L. 2003. ERK $^{\text {MAPK }}$ activity as a determinant of tumor growth and dormancy; regulation by $\mathrm{p} 38^{\mathrm{SAPK}}$. Cancer Res 63: 1684-1695.

Albrengues J, Shields MA, Ng D, Park CG, Ambrico A, Poindexter ME, Upadhyay P, Uyeminami DL, Pommier A, Küttner V, et al. 2018. Neutrophil extracellular traps produced during inflammation awaken dormant cancer 
cells in mice. Science 361: eaao4227. doi:10.1126/science .aao4227

Askmyr M, Sims NA, Martin TJ, Purton LE. 2009. What is the true nature of the osteoblastic hematopoietic stem cell niche? Trends Endocrinol Metab 20: 303-309. doi:10 .1016/j.tem.2009.03.004

Avraamides CJ, Garmy-Susini B, Varner JA. 2008. Integrins in angiogenesis and lymphangiogenesis. Nat Rev Cancer 8: 604-617. doi:10.1038/nrc2353

Bragado P, Estrada Y, Parikh F, Krause S, Capobianco C, Farina HG, Schewe DM, Aguirre-Ghiso JA. 2013. TGF$\beta 2$ dictates disseminated tumour cell fate in target organs through TGF- $\beta$-RIII and $\mathrm{p} 38 \alpha / \beta$ signalling. Nat Cell Biol 15: 1351-1361. doi:10.1038/ncb2861

Buijs JT, Henriquez NV, van Overveld PG, van der Horst G, ten Dijke P, van der Pluijm G. 2007. TGF- $\beta$ and BMP7 interactions in tumour progression and bone metastasis. Clin Exp Metastasis 24: 609-617. doi:10.1007/s10585007-9118-2

Bulavin DV, Fornace AJ Jr. 2004. p38 MAP kinase's emerging role as a tumor suppressor. Adv Cancer Res 92: 95118. doi:10.1016/S0065-230X(04)92005-2

Chen Z, Orlowski RZ, Wang M, Kwak L, McCarty N. 2014 Osteoblastic niche supports the growth of quiescent multiple myeloma cells. Blood 123: 2204-2208. doi:10.1182/ blood-2013-07-517136

Chlebowski RT, Col N. 2011. Bisphosphonates and breast cancer incidence and recurrence. Breast Dis 33: 93-101. doi:10.3233/BD-2010-0324

Coleman R, Cameron D, Dodwell D, Bell R, Wilson C, Rathbone E, Keane M, Gil M, Burkinshaw R, Grieve R, et al. 2014. Adjuvant zoledronic acid in patients with early breast cancer: final efficacy analysis of the AZURE (BIG 01/04) randomised open-label phase 3 trial. Lancet Oncol 15: 997-1006. doi:10.1016/S1470-2045(14)70302-X

Conley-LaComb MK, Semaan L, Singareddy R, Li Y, Heath EI, Kim S, Cher ML, Chinni SR. 2016. Pharmacological targeting of CXCL12/CXCR4 signaling in prostate cancer bone metastasis. Mol Cancer 15: 68. doi:10.1186/s12943016-0552-0

Cowie F, Corbett R, Pinkerton CR. 1997. Lung involvement in neuroblastoma: Incidence and characteristics. $\mathrm{Med} \mathrm{Pe}$ diatr Oncol 28: 429-432. doi:10.1002/(SICI)1096-911X (199706)28:6<429::AID-MPO7>3.0.CO;2-I

Croucher PI, McDonald MM, Martin TJ. 2016. Bone metastasis: the importance of the neighbourhood. Nat Rev Cancer 16: 373-386. doi:10.1038/nrc.2016.44

Ding L, Saunders TL, Enikolopov G, Morrison SJ. 2012. Endothelial and perivascular cells maintain haematopoietic stem cells. Nature 481: 457-462. doi:10.1038/na ture 10783

Edry Botzer L, Maman S, Sagi-Assif O, Meshel T, Nevo I, Bäuerle T, Yron I, Witz IP. 2011. Lung-residing metastatic and dormant neuroblastoma cells. Am J Pathol 179: 524 536. doi:10.1016/j.ajpath.2011.03.020

Fabian A, Stegner S, Miarka L, Zimmermann J, Lenk L, Rahn S, Buttlar J, Viol F, Knaack H, Esser D, et al. 2019. Metastasis of pancreatic cancer: an uninflamed liver micromilieu controls cell growth and cancer stem cell properties by oxidative phosphorylation in pancreatic ductal epithelial cells. Cancer Lett 453: 95-106. doi:10.1016/j .canlet.2019.03.039
Faries MB, Steen S, Ye X, Sim M, Morton DL. 2013. Late recurrence in melanoma: clinical implications of lost dormancy. J Am Coll Surg 217: 27-36. doi:10.1016/j jamcollsurg.2013.03.007

Fluegen G, Avivar-Valderas A, Wang Y, Padgen MR, Williams JK, Nobre AR, Calvo V, Cheung JF, Bravo-Cordero JJ, Entenberg D, et al. 2017. Phenotypic heterogeneity of disseminated tumour cells is preset by primary tumour hypoxic microenvironments. Nat Cell Biol 19: 120-132. doi: $10.1038 /$ ncb3465

Friberg S, Nyström A. 2015. Cancer metastases: early dissemination and late recurrences. Cancer Growth Metastasis 8: 43-49. doi:10.4137/CGM.S31244

Ghajar CM, Peinado H, Mori H, Matei IR, Evason KJ, Brazier H, Almeida D, Koller A, Hajjar KA, Stainier DY, et al. 2013. The perivascular niche regulates breast tumour dormancy. Nat Cell Biol 15: 807-817. doi:10.1038/ncb2767

Goddard ET, Bozic I, Riddell SR, Ghajar CM. 2018. Dormant tumour cells, their niches and the influence of immunity. Nat Cell Biol 20: 1240-1249. doi:10.1038/s41556-0180214-0

Greve G, Schiffmann I, Pfeifer D, Pantic M, Schüler J, Lübbert M. 2015. The pan-HDAC inhibitor panobinostat acts as a sensitizer for erlotinib activity in EGFR-mutated and -wildtype non-small cell lung cancer cells. BMC Cancer 15: 947. doi:10.1186/s12885-015-1967-5

Hadfield G. 1954. The dormant cancer cell. Br Med J 2: 607610. doi:10.1136/bmj.2.4888.607

Hamidi H, Pietilä M, Ivaska J. 2016. The complexity of integrins in cancer and new scopes for therapeutic targeting. $\mathrm{Br} J$ Cancer 115: 1017-1023. doi:10.1038/bjc.2016 .312

Jo H, Jia Y, Subramanian KK, Hattori H, Luo HR. 2008. Cancer cell-derived clusterin modulates the phosphatidylinositol $3^{\prime}$-kinase-Akt pathway through attenuation of insulin-like growth factor 1 during serum deprivation. Mol Cell Biol 28: 4285-4299. doi:10.1128/MCB.01240-07

Khoo WH, Ledergor G, Weiner A, Roden DL, Terry RL McDonald MM, Chai RC, De Veirman K, Owen KL, Opperman KS, et al. 2019. A niche-dependent myeloid transcriptome signature defines dormant myeloma cells. Blood 134: 30-43. doi:10.1182/blood.2018880930.

Kienast Y, von Baumgarten L, Fuhrmann M, Klinkert WE, Goldbrunner R, Herms J, Winkler F. 2010. Real-time imaging reveals the single steps of brain metastasis formation. Nat Med 16: 116-122. doi:10.1038/nm.2072

Kim TM, Jung SH, An CH, Lee SH, Baek IP, Kim MS, Park SW, Rhee JK, Lee SH, Chung YJ. 2015. Subclonal genomic architectures of primary and metastatic colorectal cancer based on intratumoral genetic heterogeneity. Clin Cancer Res 21: 4461-4472. doi:10.1158/1078-0432.CCR-14-2413

Kobayashi A, Okuda H, Xing F, Pandey PR, Watabe M, Hirota S, Pai SK, Liu W, Fukuda K, Chambers C, et al 2011. Bone morphogenetic protein 7 in dormancy and metastasis of prostate cancer stem-like cells in bone. $J$ Exp Med 208: 2641-2655. doi:10.1084/jem.20110840

Koebel CM, Vermi W, Swann JB, Zerafa N, Rodig SJ, Old LJ, Smyth MJ, Schreiber RD. 2007. Adaptive immunity maintains occult cancer in an equilibrium state. Nature 450: 903-907. doi:10.1038/nature06309

Kucharczyk JR, Matrana MR. 2016. Very late relapse metastatic renal cell carcinoma: characteristics and outcomes 
M.A. Summers et al.

of patients with a disease-free interval of greater than 10 years. J Clin Oncol 34: 541. doi:10.1200/jco.2016.34 .2_suppl.541

Lawson MA, McDonald MM, Kovacic N, Hua Khoo W, Terry RL, Down J, Kaplan W, Paton-Hough J, Fellows C, Pettitt JA, et al. 2015. Osteoclasts control reactivation of dormant myeloma cells by remodelling the endosteal niche. Nat Commun 6: 8983. doi:10.1038/ncomms 9983

Lenk L, Pein M, Will O, Gomez B, Viol F, Hauser C, Egberts JH, Gundlach JP, Helm O, Tiwari S, et al. 2018. The hepatic microenvironment essentially determines tumor cell dormancy and metastatic outgrowth of pancreatic ductal adenocarcinoma. Oncoimmunology 7: e1368603. doi:10.1080/2162402X.2017.1368603

Liekens S, Schols D, Hatse S. 2010. CXCL12-CXCR4 axis in angiogenesis, metastasis and stem cell mobilization. Curr Pharm Des 16: 3903-3920. doi:10.2174/ 138161210794455003

Lin YH, Friederichs J, Black MA, Mages J, Rosenberg R, Guilford PJ, Phillips V, Thompson-Fawcett M, Kasabov N, Toro T, et al. 2007. Multiple gene expression classifiers from different array platforms predict poor prognosis of colorectal cancer. Clin Cancer Res 13: 498-507. doi:10 .1158/1078-0432.CCR-05-2734

Liu G, Zhan X, Dong C, Liu L. 2017. Genomics alterations of metastatic and primary tissues across 15 cancer types. Sci Rep 7: 13262. doi:10.1038/s41598-017-13650-3

Lu X, Mu E, Wei Y, Riethdorf S, Yang Q, Yuan M, Yan J, Hua Y, Tiede BJ, Lu X, et al. 2011. VCAM-1 promotes osteolytic expansion of indolent bone micrometastasis of breast cancer by engaging $\alpha 4 \beta 1$-positive osteoclast progenitors. Cancer Cell 20: 701-714. doi:10.1016/j.ccr.2011.11.002

Macherey S, Monsef I, Jahn F, Jordan K, Yuen KK, Heidenreich A, Skoetz N. 2017. Bisphosphonates for advanced prostate cancer. Cochrane Database of Syst Rev 12: CD006250.

McNichols DW, Segura JW, DeWeerd JH. 1981. Renal cell carcinoma: long-term survival and late recurrence. J Urol 126: 17-23. doi:10.1016/S0022-5347(17)54359-1

Morgan GJ, Davies FE, Gregory WM, Cocks K, Bell SE, Szubert AJ, Navarro-Coy N, Drayson MT, Owen RG, Feyler S, et al. 2010. First-line treatment with zoledronic acid as compared with clodronic acid in multiple myeloma (MRC Myeloma IX): a randomised controlled trial. Lancet 376: 1989-1999. doi:10.1016/S0140-6736(10) 62051-X

Mowers EE, Sharifi MN, Macleod KF. 2017. Autophagy in cancer metastasis. Oncogene 36: 1619-1630. doi:10.1038/ onc. 2016.333

Naveiras O, Nardi V, Wenzel PL, Hauschka PV, Fahey F, Daley GQ. 2009. Bone-marrow adipocytes as negative regulators of the haematopoietic microenvironment. $\mathrm{Na}$ ture 460: 259-263. doi:10.1038/nature08099

Ooi LL, Zhou H, Kalak R, Zheng Y, Conigrave AD, Seibel MJ, Dunstan CR. 2010. Vitamin D deficiency promotes human breast cancer growth in a murine model of bone metastasis. Cancer Res 70: 1835-1844. doi:10.1158/ 0008-5472.CAN-09-3194

Ottewell PD, Wang N, Meek J, Fowles CA, Croucher PI, Eaton CL, Holen I. 2014. Castration-induced bone loss triggers growth of disseminated prostate cancer cells in bone. Endoc Relat Cancer 21: 769-781. doi:10.1530/ERC14-0199

Ottewell PD, Wang N, Brown HK, Fowles CA, Croucher PI, Eaton CL, Holen I. 2015. OPG-Fc inhibits ovariectomyinduced growth of disseminated breast cancer cells in bone. Int J Cancer 137: 968-977. doi:10.1002/ijc.29439

Pantel K, Schlimok G, Kutter D, Schaller G, Genz T, Wiebecke B, Backmann R, Funke I, Riethmüller G. 1991. Frequent down-regulation of major histocompatibility class I antigen expression on individual micrometastatic carcinoma cells. Cancer Res 51: 4712-4715.

Price TT, Burness ML, Sivan A, Warner MJ, Cheng R, Lee $\mathrm{CH}$, Olivere L, Comatas K, Magnani J, Kim Lyerly H, et al. 2016. Dormant breast cancer micrometastases reside in specific bone marrow niches that regulate their transit to and from bone. Sci Transl Med 8: 340ra373. doi:10.1126/ scitranslmed.aad4059

Prunier C, Baker D, ten Dijke P, Ritsma L. 2019. TGF- $\beta$ family signaling pathways in cellular dormancy. Trends Cancer 5: 66-78. doi:10.1016/j.trecan.2018.10.010

Quaresma M, Coleman MP, Rachet B. 2015. 40-year trends in an index of survival for all cancers combined and survival adjusted for age and sex for each cancer in England and Wales, 1971-2011: A population-based study. Lancet 385: 1206-1218. doi:10.1016/S0140-6736(14)61396-9

Ranganathan AC, Zhang L, Adam AP, Aguirre-Ghiso JA. 2006. Functional coupling of p38-induced up-regulation of BiP and activation of RNA-dependent protein kinaselike endoplasmic reticulum kinase to drug resistance of dormant carcinoma cells. Cancer Res 66: 1702-1711. doi:10.1158/0008-5472.CAN-05-3092

Roesch A, Vultur A, Bogeski I, Wang H, Zimmermann KM, Speicher D, Körbel C, Laschke MW, Gimotty PA, Philipp SE, et al. 2013. Overcoming intrinsic multidrug resistance in melanoma by blocking the mitochondrial respiratory chain of slow-cycling JARID1B ${ }^{\text {high }}$ cells. Cancer Cell 23: 811-825. doi:10.1016/j.ccr.2013.05.003

Saleh D, Peach AH. 2011. Ultra-late recurrence of malignant melanoma after 40 years of quiescent disease. J Surg Oncol 103: 290-291. doi:10.1002/jso.21821

Schewe DM, Aguirre-Ghiso JA. 2008. ATF6 $\alpha$-Rheb-mTOR signaling promotes survival of dormant tumor cells in vivo. Proc Natl Acad Sci 105: 10519-10524. doi:10 $.1073 /$ pnas.0800939105

Sharma SV, Lee DY, Li B, Quinlan MP, Takahashi F, Maheswaran S, McDermott U, Azizian N, Zou L, Fischbach MA, et al. 2010. A chromatin-mediated reversible drug-tolerant state in cancer cell subpopulations. Cell 141: 69-80. doi:10.1016/j.cell.2010.02.027

Shiozawa Y, Pedersen EA, Patel LR, Ziegler AM, Havens AM, Jung Y, Wang J, Zalucha S, Loberg RD, Pienta KJ, et al. 2010a. GAS6/AXL axis regulates prostate cancer invasion, proliferation, and survival in the bone marrow niche. Neoplasia 12: 116-127. doi:10.1593/neo.91384

Shiozawa Y, Pedersen EA, Taichman RS. 2010b. GAS6/Mer axis regulates the homing and survival of the E2A/PBX1positive B-cell precursor acute lymphoblastic leukemia in the bone marrow niche. Exp Hematol 38: 132-140. doi:10 .1016/j.exphem.2009.11.002

Shiozawa Y, Pedersen EA, Havens AM, Jung Y, Mishra A, Joseph J, Kim JK, Patel LR, Ying C, Ziegler AM, et al. 2011. Human prostate cancer metastases target the hematopoi- 
etic stem cell niche to establish footholds in mouse bone marrow. J Clin Invest 121: 1298-1312. doi:10.1172/ JCI43414

Singh M, Manoranjan B, Mahendram S, McFarlane N, Venugopal C, Singh SK. 2014. Brain metastasis-initiating cells: survival of the fittest. Int J Mol Sci 15: 9117-9133. doi:10.3390/ijms15059117

Sosa MS, Bragado P, Aguirre-Ghiso JA. 2014. Mechanisms of disseminated cancer cell dormancy: an awakening field. Nat Rev Cancer 14: 611-622. doi:10.1038/nrc3793

Stupack DG, Cheresh DA. 2004. Integrins and angiogenesis. Curr Top Dev Biol 64: 207-238. doi:10.1016/S0070-2153 (04)64009-9

Sugiyama T, Kohara H, Noda M, Nagasawa T. 2006. Maintenance of the hematopoietic stem cell pool by CXCL12CXCR4 chemokine signaling in bone marrow stromal cell niches. Immunity 25: 977-988. doi:10.1016/j.immuni .2006 .10 .016

Taichman RS, Patel LR, Bedenis R, Wang J, Weidner S, Schumann T, Yumoto K, Berry JE, Shiozawa Y, Pienta KJ. 2013. GAS6 receptor status is associated with dormancy and bone metastatic tumor formation. PLoS ONE 8: e61873. doi:10.1371/journal.pone.0061873

Teng MW, Vesely MD, Duret H, McLaughlin N, Towne JE Schreiber RD, Smyth MJ. 2012. Opposing roles for IL-23 and IL-12 in maintaining occult cancer in an equilibrium state. Cancer Res 72: 3987-3996. doi:10.1158/0008-5472 .CAN-12-1337

Terhorst D, Radke C, Trefzer U. 2010. Ultra-late recurrence of malignant melanoma after a disease-free interval of 41 years. Clin Exp Dermatol 35: e20-e21. doi:10.1111/j .1365-2230.2009.03330.x

Toulmonde M, Le Cesne A, Mendiboure J, Blay JY, PipernoNeumann S, Chevreau C, Delcambre C, Penel N, Terrier P, Ranchère-Vince D, et al. 2014. Long-term recurrence of soft tissue sarcomas: prognostic factors and implications for prolonged follow-up. Cancer 120: 3003-3006. doi:10 $.1002 /$ cncr. 28836

van der Toom EE, Verdone JE, Pienta KJ. 2016. Disseminated tumor cells and dormancy in prostate cancer metasta- sis. Curr Opin Biotechnol 40: 9-15. doi:10.1016/j.copbio .2016 .02 .002

Viale A, Pettazzoni P, Lyssiotis CA, Ying $\mathrm{H}$, Sánchez $\mathrm{N}$, Marchesini M, Carugo A, Green T, Seth S, Giuliani V, et al. 2014. Oncogene ablation-resistant pancreatic cancer cells depend on mitochondrial function. Nature 514: 628-632. doi:10.1038/nature13611

Willis RA. 1934. The spread of tumours in the human body. J\&A Churchill Publishers, London. doi.org/10.1002/ bjs. 1800228544.

Wilson A, Oser GM, Jaworski M, Blanco-Bose WE, Laurenti E, Adolphe C, Essers MA, MacDonald HR, Trumpp A. 2007. Dormant and self-renewing hematopoietic stem cells and their niches. Ann NY Acad Sci 1106: 64-75. doi:10.1196/annals.1392.021

Wilson A, Laurenti E, Oser G, van der Wath RC, BlancoBose W, Jaworski M, Offner S, Dunant CF, Eshkind L, Bockamp E, et al. 2008. Hematopoietic stem cells reversibly switch from dormancy to self-renewal during homeostasis and repair. Cell 135: 1118-1129. doi:10.1016/j.cell .2008 .10 .048

Yeh AC, Ramaswamy S. 2015. Mechanisms of cancer cell dormancy-another hallmark of cancer? Cancer Res 75: 5014-5022. doi:10.1158/0008-5472.CAN-15-1370

Yu-Lee LY, Yu G, Lee YC, Lin SC, Pan J, Pan T, Yu KJ, Liu B, Creighton CJ, Rodriguez-Canales J, et al. 2018. Osteoblast-secreted factors mediate dormancy of metastatic prostate cancer in the bone via activation of the TGFßRIII-p38MAPK-pS249/T252RB pathway. Cancer Res 78: 2911-2924. doi:10.1158/0008-5472.CAN-171051

Yumoto K, Eber MR, Wang J, Cackowski FC, Decker AM, Lee E, Nobre AR, Aguirre-Ghiso JA, Jung Y, Taichman RS. 2016. Axl is required for TGF- $\beta 2$-induced dormancy of prostate cancer cells in the bone marrow. Sci Rep 6: 36520. doi: $10.1038 /$ srep36520

Zhang XHF, Giuliano M, Trivedi MV, Schiff R, Osborne CK. 2013. Metastasis dormancy in estrogen receptor-positive breast cancer. Clin Cancer Res 19: 6389-6397. doi:10 .1158/1078-0432.CCR-13-0838 


\section{$\&_{\mathrm{CSH}}^{\infty} \&$ Cold Spring Harbor

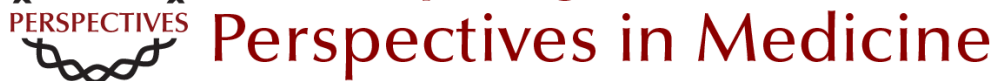

\section{Cancer Cell Dormancy in Metastasis}

Matthew A. Summers, Michelle M. McDonald and Peter I. Croucher

Cold Spring Harb Perspect Med 2020; doi: 10.1101/cshperspect.a037556 originally published online September 23, 2019

\section{Subject Collection Metastasis: Mechanism to Therapy}

Cellular Plasticity during Metastasis: New Insights Provided by Intravital Microscopy Andreia S. Margarido, Laura Bornes, Claire Vennin, et al.

The Etiology and Impact of Muscle Wasting in Metastatic Cancer Anup K. Biswas and Swarnali Acharyya

Normal Aging and Its Role in Cancer Metastasis Mitchell Fane and Ashani T. Weeraratna

\section{Zebrafish In Vivo Models of Cancer and Metastasis \\ Katy R. Astell and Dirk Sieger \\ Extracellular Vesicles and Metastasis Shizhen Emily Wang}

The Different Facets of Liquid Biopsy: A Kaleidoscopic View

Zahra Eslami-S, Luis Enrique Cortés-Hernández, Laure Cayrefourcq, et al.

Myeloid Cells in Metastasis Agnieszka Swierczak and Jeffrey W. Pollard

Cancer Cell Dormancy in Metastasis Matthew A. Summers, Michelle M. McDonald and Peter I. Croucher

\section{Premetastasis \\ Yoshiro Maru}

Bone Tropism in Cancer Metastases Hai Wang, Weijie Zhang, Igor Bado, et al.

Impact of Immunometabolism on Cancer Metastasis: A Focus on T Cells and Macrophages Nina C. Flerin, Sotiria Pinioti, Alessio Menga, et al.

New Approaches on Cancer Immunotherapy Jong-Ho Cha, Li-Chuan Chan, Min Sup Song, et al.

Cancer Stem Cells and Epithelial-to-Mesenchymal Transition in Cancer Metastasis Toni Celià-Terrassa and Mohit Kumar Jolly

Clinical Perspectives in Brain Metastasis Krutika Deshpande, lan Buchanan, Vahan Martirosian, et al.

Brain Metastasis Organotropism Arseniy E. Yuzhalin and Dihua Yu

The Immune Microenvironment and Cancer Metastasis Asmaa El-Kenawi, Kay Hänggi and Brian Ruffell

For additional articles in this collection, see http://perspectivesinmedicine.cshlp.org/cgi/collection/ 